\title{
Infantlarda Serum Prolidaz Aktivitesinin Oksidatif ve Nonoksidatif Durumda Gelişimsel Kalça Displazi Hastalığı ile iliş̧kisi
}

Relationship of Serum Prolidase Activity with Developmental Hip Dysplasia Disease in Oxidative and Non-Oxidative Status in Infants

\author{
Emrah VATANSEVER ${ }^{1}$ (D) Baki Volkan ÇETiN ${ }^{1}$ (D), Mehmet Akif ALTAY ${ }^{1}$, Ahmet Yiğit KAPTAN ${ }^{1}$ (D), \\ Sedat DEMIR ${ }^{1}$, Metin YAPTI ${ }^{2}$ (D)
}

\begin{abstract}
${ }^{1}$ Harran Üniversitesi Tıp Fakültesi, Ortopedi ve Travmatoloji Anabilim Dalı, Şanlıurfa, TÜRKIYE
${ }^{2}$ Mehmet Akif İnan Eğitim ve Araştırma Hastanesi, Ortopedi ve Travmatoloji, Şanlıurfa, TÜRKiYE
\end{abstract}

öz.

Amaç: Gelişimsel kalça displazili (GKD) hastaların tedavi sürecinde serum prolidaz aktivitesinin oksidatifnonoksidatif durumlarda takip edilerek, tedavi ve takip parametresi olarak serum prolidaz aktivitesinin kullanımını araştırmayı amaçladık.

Materyal ve Metod: Prospektif olarak gerçekleştirilen bu çalışma, 0-6 ay arasındaki 30 GKD'li bebek ve 0-6 ay arasındaki 30 sağlıklı bebekten oluşan iki grubu içermektedir. Hasta grubunda yer alan bebeklerden 3 kez, kontrol grubundaki bebeklerden 1 kez olmak üzere kan örnekleri alındı. Bu kanlarda total antioksidan stres (TAS), total oksidatif stres (TOS), oksidatif stres indeksi (OSI) ve prolidaz enzim aktvitesine bakıldı. Sonuçlar kendi aralarında karşılaştıııldı.

Bulgular: Tedaviye başlamadan önce hasta ve sağıklı bebeklerden alınan kanlarda bakılan TOS, OSı ve serum prolidaz seviyelerinin kontrol grubundaki bebeklere kıyasla hasta grubunda yer alan bebeklerde anlamlı bir şekilde daha yüksek olduğu tespit edildi. TAS seviyesinin ise kontrol grubuna oranla düşük olduğu tespit edildi. Hasta bebeklere uygulanan 6 haftalık pavlik bandaj tedavisinin ardından hasta bebeklerin TAS, TOS, OSI ve serum prolidaz seviyelerinde istatistiksel olarak kontrol grubu ile uyumlu olacak şekilde düzelme gözlemlendi. Sonuç: Artan TOS ve OSI seviyelerinin bu hastalık bağlamında oksidatif strese neden olduğu ve dejeneratif hastalıklarda görüldüğü gibi artmış prolidaz aktivitesinin artmış kolajen metabolizmasına neden olduğu sonucuna varılmıştır. GKD şiddetini değerlendirmede ve tedavinin takibinde serum prolidaz aktivitesi ve oksidatif-nonoksidatif durum parametrelerinin yardımcı birer araç olabileceğini söyleyebiliriz.

Anahtar Kelimeler: Gelişimsel kalça displazisi, Prolidaz enzim aktivitesi, Total antioksidan stres, Total oksidatif stres, Oksidatif stres indeksi

\section{Abstract}

Background: We aimed to investigate the use of serum prolidase activity as a treatment and follow-up parameter by following the oxidative and nonoxidative status of serum prolidase activity during the treatment process of patients with developmental hip dysplasia (DDH).

Materials and Methods: This prospective study includes two groups of 30 babies with DDH between $0-6$ months and 30 healthy babies between 0-6 months. Blood samples were taken 3 times from the babies in the patient group and once from the babies in the control group. Total antioxidant stress (TAS), total oxidative stress (TOS), oxidative stress index (OSI) and prolidase enzyme activity were measured in these blood samples. The results were compared each others.

Results: TOS, OSI and serum prolidase levels were found to be significantly higher in the babies in the patient group compared to the control group. TAS level was found to be lower than the control group. After 6 weeks of pavilic harness treatment applied to the patients group, an improvement was observed in the TAS, TOS, OSI and serum prolidase levels of the patients group, Statistically, they got closer each other.

Conclusion: It was concluded that increased TOS and OSI levels cause oxidative stress in the context of this disease and increased prolidase activity causes increased collagen metabolism as seen in degenerative diseases. We can say that serum prolidase activity and oxidative-nonoxidative status parameters can be helpful tools in the evaluation of DDH severity and follow-up of treatment.

Key Words: Developmental dysplasia of the hip, Prolidase enzyme activity, Total antioxidant stress, Total oxidative stress, Oxidative stress index.
Sorumlu Yazar/Corresponding Author

\section{Dr. Emrah VATANSEVER}

Harran Üniversitesi Tıp Fakültesi Ortopedi ve Travmatoloji Anabilim Dalı, Osmanbey Kampüsü, Şanlıurfa, TÜRKIYE

E-mail: doctor.emrah@gmail.com

Geliş tarihi / Received: 21.04.2021

Kabul tarihi / Accepted: 05.07.2021

DOI: 10.35440/hutfd.923840

Bu çalışma Dr. Emrah Vatansever'in tıpta uzmanlık tezinden türetilmiştir. 


\section{Giriş}

Kolajen metabolizmasında önemli bir rol oynayan prolidaz (1), özellikle imidodipeptidleri C-terminal prolin veya hidroksiproline ayıran sitozolik bir enzimdir (2). Prolidaz, kolajen biyosentezinin düzenlenmesinde hız sınırlayıcı bir faktördür (3). Prolidaz, kolajenin sarmal yapısında C-terminal prolin veya hidroksiprolin kalıntıları içeren imidodipeptitleri parçalayıp serbest bırakarak kolajen sentezine ve hücre büyümesine neden olur (4). İmidodipeptitler, hücre içi ve hücre dışı kolajen formlarının, diyet proteinlerin ve diğer prolin içeren protenlerin metabolizması sonucu ortaya çıkar (5).

GKD'li vakaların eklem kapsüllerindeki kolajen tipi, fibril çapı ve çapraz bağların doğasında önemli değişiklikler bildirilmiştir $(6,7)$. GKD'nin kolajen yapısındaki bu değişiklik, kolajen yapım ve yıkım döngüsünde artışa yol açar. Artan kolajen sentez oranının, kolajen liflerinin kalitesinde bir değişikliğe yol açabileceği bilinmektedir. Bağ dokunun devamlıIığını sağlayan ana doku olan ve kemik, bağ doku, tendon, kas ve eklem kıkırdağı gibi dokuların ortak komponenti olan kollajen, GKD hastalarında serum konsantrasyon seviyesi sağııkı bireylerden daha fazladır. Altay ve ark.'nın 2017 yılında yaptıkları bir çalışmada, prolidaz enziminin GKD' de oksidatif-nooksidaf durum ile prolidaz aktivitesi arasında bir ilişki olduğu gösterilmiştir (8). Bu çalışmanın amacı infantlarda GKD tedavisi sırasında oksidatif-nonoksidatif durum ile serum prolidaz aktivitesi arasındaki ilişkiyi değerlendirmektir.

\section{Materyal ve Metod}

Araştırma Harran Üniversitesi Tıp Fakultesi Klinik Araştırmalar Etik Kurulu tarafından onaylanmıştır (Tarih: 14.01.2018; 01 no'lu oturum ve 11 sayılı karar). Prospektif olarak planlanan bu çalışma 2018-2019 yılları arasında Harran Üniversitesi Eğitim ve Araştırma Hastanesi'ne başvurarak GKD tanısı alan ve herhangi bir ek hastalığı bulunmayan 0-6 ay arasındaki 30 hasta bebekten oluşan hasta grubunu ve 0-6 ay arasındaki 30 sağlıklı bebeğin yer aldığı kontrol grubunu içermektedir. Kontrol grubunda yer alan 30 sağ ıklı bebekten bir kez, 30 hasta bebekten 0 . hafta, 3. hafta ve 6 . hafta olacak şekilde üç kez vakumlu vacutainer tüplere $5 \mathrm{cc}$ kan alındı. Alınan kan örnekleri oda ısısında düz tüp raklarında 30 dakika bekletildi. Ardından bu kanlar 3000 devir/dakika hız ile santrifüj cihazında 10 dakika santrifüj edilerek serumlarına ayrıldı. TAS, TOS, OSI ve prolidaz enzim seviyesi çalışılabilmesi amacıyla kanların serumları -80 ${ }^{0} C^{\prime}$ de depolanarak muhafaza edildi. Çalışmanın yapılacağı zaman tüm serum örnekleri oda ısısına getirildikten sonra çalışıldı. Hastalardan alınan kanlar, kan alınma haftasına göre sırasıyla Grup 1, Grup 2 ve Grup 3 olarak ve kontrol grubundaki sağlıklı bebeklerden alınan kanlar Kontrol Grubu olarak adlandırıldı. Her grup için TAS, TOS, OSI ve Prolidaz enzim seviyelerine bakıldı. Grup 1 için TAS 1 , TOS 1, OSI 1, Prolidaz 1; Grup 2 için TAS 2, TOS 2, OSI 2,
Prolidaz 2; Grup 3 için TAS 3, TOS 3, OSI 3, Prolidaz 3 ve Kontrol Grubu için TAS Kontrol, TOS Kontrol, OSI Kontrol, Prolidaz Kontrol çalışıldı ve elde edilen serum sonuçları kaydedildi. Kaydedilen sonuçlar SPSS 21.0 programı üzerinde analiz edildi. Her grup için elde edilen sonuçların kendi aralarında Student's t testine göre anlamlı değişiklikler olup olmadığı araştırıldı. Analizler sonucunda “0,005”ten küçük olan " $p$ " değeri gruplar arasındaki farkın anlamlılık değeri olarak kabul edildi.

\section{Bulgular}

Tablo 1'de hasta grubu ve kontrol grubunun TAS seviyelerine bakılmıştır. Tablodaki veriler dikkate alındığında TAS 1 ve TAS 3 parametreleri arasında $(p=0,001)$, TAS 1 ve TAS Kontrol parametreleri arasında $(p=0,001)$ ve TAS 2 ve TAS Kontrol parametreleri arasında $(p=0,004)$ istatistikî açıdan anlamlı bir farklılık olduğu tespit edildi. Hasta grubunun TAS seviyesi başlangıçta kontrol grubuna kıyasla önemli oranda düşük iken, tedavi sonunda iki grubun değerleri birbirine yaklaşmıştır.

Tablo 1. Hastaların ve Kontrol Grubunun TAS karşılaştırmalarına göre dağılımları ${ }^{1}$

\begin{tabular}{lccc}
\hline & Ort \pm SS & T & P \\
\hline TAS 1 & $1,14 \pm 0,36$ & $-2,997$ & 0,006 \\
TAS 2 & $1,35 \pm 0,22$ & & \\
\hline TAS 1 & $1,14 \pm 0,36$ & $-4,035$ & 0,001 \\
TAS 3 & $1,44 \pm 0,18$ & & \\
\hline TAS 2 & $1,35 \pm 0,22$ & $-1,719$ & 0,096 \\
TAS 3 & $1,44 \pm 0,18$ & & \\
\hline TAS 1 & $1,14 \pm 0,36$ & 5,383 & 0,001 \\
TAS Kontrol & $1,53 \pm 0,21$ & & \\
\hline TAS 2 & $1,35 \pm 0,22$ & 3,098 & 0,004 \\
TAS Kontrol & $1,53 \pm 0,21$ & & \\
\hline TAS 3 & $1,44 \pm 0,18$ & 1,945 & 0,062 \\
TAS Kontrol & $1,53 \pm 0,21$ & & \\
\hline 1 Studentst testi & $0,01,005)$ & &
\end{tabular}

1 Student's $t$ testi $(0,001-0,005)$

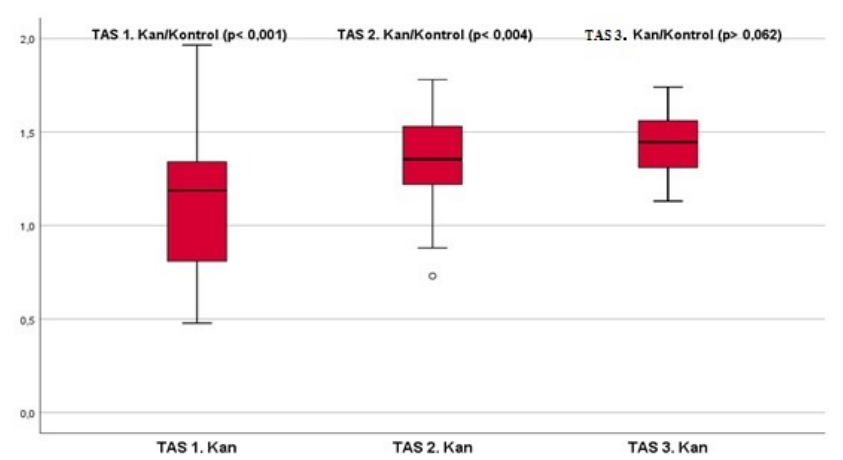

Şekil 1. Box plots analizine göre TAS 1, TAS 2ve TAS 3 kan değerlerinin kontrol grubu ile ilişkisi

Tablo 2'de hasta grubu ve kontrol grubunun TOS seviyelerine bakılmıştır. TOS 1 ve TOS Kontrol parametreleri ara- 
sında $(p=0,001)$ ve TOS 2 ve TOS Kontrol parametreleri arasında $(p=0,004)$ istatistikî açıdan anlamlı bir farklılık olduğu tespit edildi. Hasta grubunun TOS seviyesi başlangıçta kontrol grubuna kıyasla önemli oranda yüksek iken, tedavi sonunda iki grubun değerleri birbirine yaklaşmıştır.

Tablo 2. Hastaların ve Kontrol Grubunun TOS karşılaştırmalarına göre dağılımları ${ }^{2}$

\begin{tabular}{lccc}
\hline & Ort \pm SS & $\mathbf{T}$ & $\mathbf{P}$ \\
\hline TOS 1 & $14,12 \pm 2,01$ & 1,440 & 0,161 \\
TOS 2 & $13,44 \pm 2,32$ & & \\
\hline TOS 1 & $14,12 \pm 2,01$ & 2,929 & 0,007 \\
TOS 3 & $12,55 \pm 2,26$ & & \\
\hline TOS 2 & $13,44 \pm 2,32$ & 1,385 & 0,177 \\
TOS 3 & $12,55 \pm 2,26$ & & \\
\hline TOS Kontrol & $11,05 \pm 2,00$ & $-6,174$ & 0,001 \\
TOS 1 & $14,12 \pm 2,01$ & & \\
\hline TOS Kontrol & $11,05 \pm 2,00$ & $-4,198$ & 0,001 \\
TOS 2 & $13,44 \pm 2,32$ & & \\
\hline TOS Kontrol & $11,05 \pm 2,00$ & $-2,765$ & 0,010 \\
TOS 3 & $12,55 \pm 2,26$ & & \\
\hline 2 & & &
\end{tabular}

${ }^{2}$ Student's t testi $(0,001-0,005)$

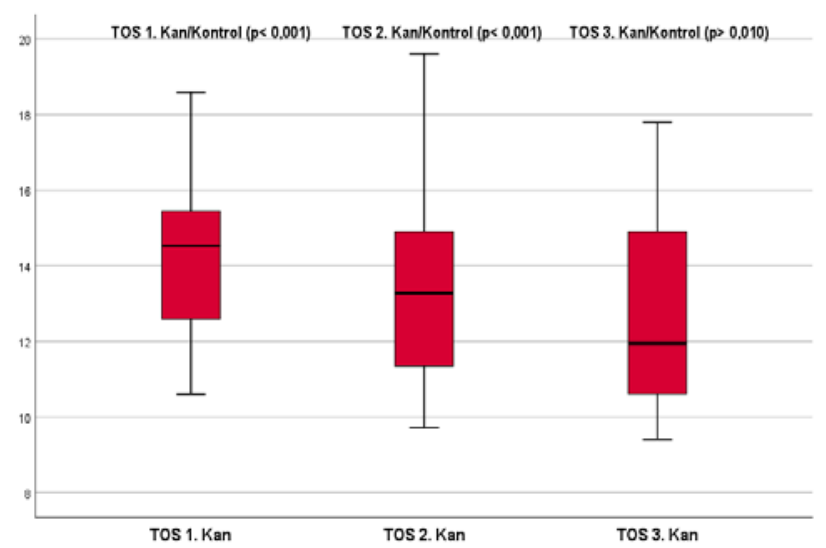

Şekil 2. Box plots analizine göre TOS 1 , TOS 2 ve TOS 3 kan değerlerinin kontrol grubu ile ilişkisi

Tablo 3'te hasta grubu ve kontrol grubunun OSI seviyelerine bakılmıştır. OSI 1 ve OSI 2 parametreleri arasında $(p=0,003)$, OSI 1 ve OSI 3 parametreleri arasında $(p=0,001)$, OSI 1 ve OSI Kontrol parametreleri arasında $(p=0,001)$, OSI 2 ve OSI Kontrol parametreleri arasında $(p=0,001)$ ve OSI 3 ve OSI Kontrol parametreleri arasında $(p=0,001)$ istatistikî açıdan anlamlı bir farklılık olduğu tespit edildi. Hasta grubunun OSI seviyesi başlangıçta kontrol grubuna kıyasla önemli oranda yüksek iken, tedavi sonunda iki grubun değerleri birbirine yaklaşmıştır.

Tablo 4'te hasta grubu ve Kontrol Grubunun prolidaz enzim seviyelerine bakılmıştır. Analizler sonucunda Prolidaz 1 ve Prolidaz Kontrol parametreleri arasında $(p=0,001)$ istatistikî açıdan anlamlı bir farklılık olduğu tespit edildi. Hasta grubunun prolidaz enzim seviyesi başlangıçta kontrol grubuna kıyasla önemli oranda yüksek iken, tedavi sonunda iki grubun değerleri birbirine yaklaşmıştır.
Tablo 3. Hastaların ve Kontrol Grubunun OSI karşılaştırmalarına göre dağılımları ${ }^{3}$

\begin{tabular}{lccc}
\hline & Ort \pm SS & T & P \\
\hline OSI 1 & $1,41 \pm 0,64$ & 3,229 & 0,003 \\
OSI 2 & $1,03 \pm 0,27$ & & \\
\hline OSI 1 & $1,41 \pm 0,64$ & 4,484 & 0,001 \\
OSI 3 & $0,89 \pm 0,23$ & & \\
\hline OSI 2 & $1,03 \pm 0,27$ & 2,084 & 0,046 \\
OSI 3 & $0,89 \pm 0,23$ & & \\
\hline OSI Kontrol & $0,47 \pm 0,07$ & $-8,429$ & 0,001 \\
OSI 1 & $1,41 \pm 0,64$ & & \\
\hline OSI Kontrol & $0,47 \pm 0,07$ & $-11,170$ & 0,001 \\
OSI 2 & $1,03 \pm 0,27$ & & \\
\hline OSI Kontrol & $0,47 \pm 0,07$ & $-9,907$ & 0,001 \\
OSI 3 & $0,89 \pm 0,23$ & & \\
\hline SStudent'st testi & & &
\end{tabular}

${ }^{3}$ Student's t testi $(0,001-0,005)$

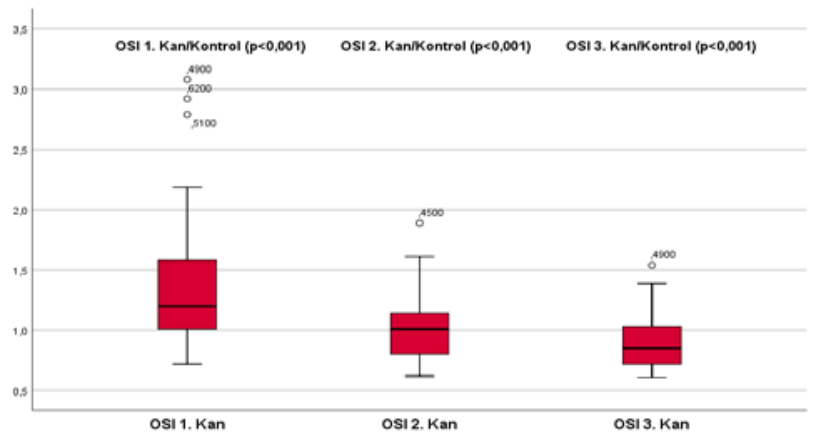

Şekil 3. Box plots analizine göre OSI 1, OSI 2 ve OSI3 kan değerlerinin kontrol grubu ile ilişkisi.

Tablo 4. Hastaların ve Kontrol Grubunun Prolidaz enzim seviyelerine göre dağılımları ${ }^{4}$

\begin{tabular}{lccc}
\hline & Ort \pm SS & T & P \\
\hline Prolidaz1 & $101,90 \pm 27,03$ & 0,796 & 0,432 \\
Prolidaz 2 & $94,63 \pm 38,79$ & & \\
\hline Prolidaz1 & $101,90 \pm 27,03$ & 1,459 & 0,155 \\
Prolidaz 3 & $90,82 \pm 25,46$ & & \\
\hline Prolidaz 2 & $94,63 \pm 38,79$ & 0,437 & 0,665 \\
Prolidaz 3 & $90,82 \pm 25,46$ & & \\
\hline Prolidaz Kontrol & $77,79 \pm 25,38$ & $-3,808$ & 0,001 \\
Prolidaz1 & $101,90 \pm 27,03$ & & \\
\hline Prolidaz Kontrol & $77,79 \pm 25,38$ & $-2,125$ & 0,042 \\
Prolidaz 2 & $94,63 \pm 38,79$ & & \\
\hline Prolidaz Kontrol & $77,79 \pm 25,38$ & $-2,202$ & 0,036 \\
Prolidaz 3 & $90,82 \pm 25,46$ & & \\
\hline
\end{tabular}

4 Student's t testi $(0,001-0,005)$

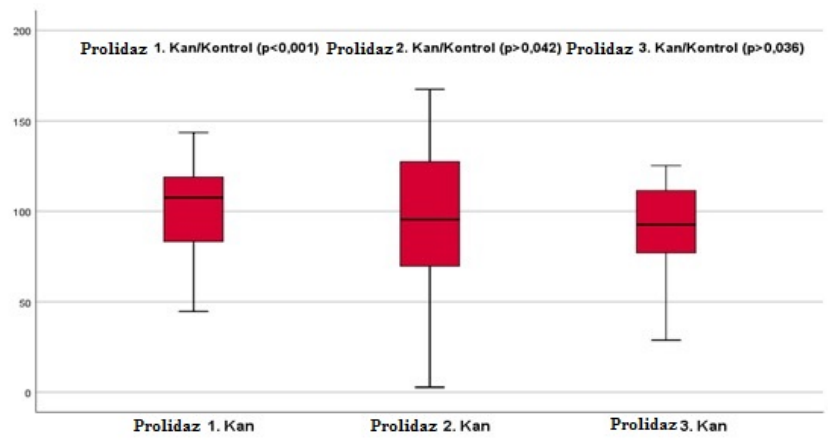

Şekil 4. Box plots analizine göre Prolidaz 1, Prolidaz 2 ve Prolidaz 3 kan değerlerinin kontrol grubu ile ilişkisi. 


\section{Tartışma}

Dış orbitallerinde eşlenmemiş elektron içeren moleküler yapılar olan serbest oksijen radikalleri (ROS), hücrede sürekli olarak üretilirler (9). Serbest radikaller ile reaktif karakterli tüm maddeleri üreten faktörlere oksidan adı verilir (10). Vücutta üretilen ROS'ların pek çok dejeneratif hastalığa neden olduğu bilinmektedir (11). Sürekli olarak ROS ataklarıyla karşı karşıya olan organizma (12), bu duruma karşı koymak için çeşitli antioksidan savunma mekanizmaları geliştirir (13). Nonoksidanlar ROS'un etkilerini minimalize ederek nötrleştirilmesini sağlar (14). Oksidan/nonoksidan dengesi organizmanın sağlıklı olmasını sağlar (12). Oksidan seviyesinin artması ve/veya nonoksidan seviyesinin azalması sonucunda oksidatif/nonoksidatif dengenin oksidanlar lehine bozulması oksidatif strese neden olur $(9,14$, 15). Oksidatif stresin hafif olması durumunda nonoksidanlar savunma yaparak organizmanın sağlıklı kalmasını sağlarken oksidatif stresin şiddetli olması durumunda hücre hasarı ve ölümüne neden olabilir (16). OSI değeri TOS değerlerinin TAS değerleri ile bölünmesi ile hesaplanır (14). OSI değerlerini yüksek olması durumunda lipitler, proteinler ve nükleik asitler de dâhil bütün hücresel elemanlar zarar görür (15). Çalışmamızda tedavinin başında hasta ve sağlıklı bebeklerden alınan kanlar karşılaştırıldığında GKD’li bebeklerin TAS değerlerinin kontrol grubuna kıyasla anlamlı derecede düşük olduğu görülmüştür. TOS değerlerinin ise kontrol grubuna kıyasla anlamlı şekilde yüksek olduğu tespit edilmiştir. TOS değerlerinin TAS değerine bölümü sonucu elde edilen OSI değerlerinin ise anlamlı bir şekilde yüksek olduğu sonucuna ulaşılmıştır. GKD tespit edilen ve 6 hafta boyunca pavlik bandaj yöntemi ile tedavi edilen bebeklerin kalçaları redükte olduğunda TAS değerleri anlamlı bir şekilde yükselirken, TOS ve OSI değerleri de düşmüş ve GKD'li bebeklerin oksidan/nonoksidan seviyelerinin kontrol grubundaki bebeklerin seviyesine yaklaştığı görülmüştür.

Oksidatif stresten etkilenen serum prolidaz enzim aktivitesi son aşamada kollajen parçalanmasında önemli bir rol oynar. Prolidaz aktivitesi geniş yelpazedeki hastalıklarda görülmektedir. Birçok çalışmada, osteoartrit (17), üremik kemik hastalığı (18) ve osteogenezis imperfekta (19) gibi hastalıklarda prolidaz aktivitesinin azaldığı, ama Legg-CalvePerthes hastalığında (20) ve idiyopatik çarpık ayaklarda prolidaz aktivitesinin arttığı bildirilmiştir (3). Literatürde yapılan çalışmalarda da benzer şekilde reaktif oksijen türlerinin seviyesinin arttığı gösterilmiştir (3, 20, 21, 22). GKD dışında herhangi bir prolidaz enzim seviyesini yükseltecek bir hastalık bulunmayan hastalar üzerinde yapılan ve oksidatif/nonoksidatif durumun değerlendirildiği bu çalışmada da benzer bulgulara ulaşılmıştır. Tedavinin başında GKD'li bebeklerde kontrol grubuna kıyasla anlamlı şekilde yüksek olan serum prolidaz enzim seviyesi tedavi sürecinde düşme eğilimi göstererek tedavinin sonunda kontrol grubunun değerlerine yaklaşmıştır. Serum prolidaz enzim seviyesi, uygulanan başarılı tedavi sonucunda düşmektedir. İnfant GKD'li hastalarda serum prolidaz aktivitesinin oksidatif ve nonoksidatif durumlarının değerlendirildiği bu çalışmada infant
GKD'li hastalarda prolidaz enzim seviyesinin tedavi öncesi kontrol grubundan anlamlı olarak yüksek, tedavi sonrası ise düşerek kontrol grubu seviyesine yaklaştığı bulgusuna ulaşılmıştır. Literatürde geniş serilerde yapılacak çalışmalardan sonra, prolidaz seviyesi GKD hastalarında tedavinin takibinde kullanılması tartışılabilir.

Çalışmamız GKD’nin erken teşhisinin sağlanması ve bebeklerin büyük operasyonlara gerek kalmaksızın erken dönemde tedavi edilebilmesi açısından büyük bir öneme sahiptir. Ancak bu çalışmamızın bazı önemli kısıtlılıkları bulunmaktadır. Öncelikle GKD hastalarında prolidaz aktivitesi hastalık evresine göre değerlendirilmemiştir. Ayrıca hastaların tedaviye başlangıç yaşları da farklılık göstermektedir. Bununla beraber gelecekte literatürde hastalık evresi ve tedavi başlangıç yaşını da dikkate alarak yapılacak çalışmalarla prolidaz enzim seviyesinin tanı ve tedavi takibinde kullanımının mümkün olabileceğini düşünüyoruz.

6 hafta süren takipler sonucunda prolidaz enzim seviyesi ile GKD arasında bir ilişki olduğu sonucuna varılmıştır. Ancak bu çalışmaya dayanarak GKD’li bebeklerde yüksek olan oksidatif stresin GKD’nin nedeni mi yoksa sonucu mu olduğunu söylemek mümkün değildir. TAS ve TOS seviyelerinin bu hastalık bağlamında oksidatif strese neden olduğu ve dejeneratif hastalıklarda görüldüğü gibi artmış prolidaz aktivitesinin artmış kolajen metabolizmasına neden olduğu sonucuna varmak kesinlikle mümkündür. Bununla birlikte, biyokimyasal parametrelerde meydana gelen yukarıda belirtilen değişiklikler GKD'nin sistematik bir bozukluk olduğuna işaret ediyor olabilir, ancak tek taraflı GKD görülen hastalarda ise diğer eklemlerin nasıl olup da hasar görmediği ise bilinmemektedir. Bu noktayı açıklığa kavuşturmak için daha yüksek sayıdaki örneklem üzerinde daha ayrıntılı klinik çaıışmalara ihtiyaç vardır.

Etik onam: Çalışma için 04/01/2018 tarihli, 01 no'lu oturum ve 11 sayılı kararı ile Harran Üniversitesi Tıp Fakültesi Klinik Araştırmalar Etik Kurulu'ndan onay alındı.

\section{Yazar Katkıları:}

Konsept: E.V.

Literatür Tarama: E.V., B.V.Ç, S.D.

Tasarım: E.V, B.V.C, A.Y.K.

Veri toplama: E.V, S.D.

Analiz ve yorum: B.V.Ç, M.Y.

Makale yazımı: E.V, B.V.C., M.A.A

Eleştirel incelenmesi: M.A.A, B.V.Ç, A.Y.K.

Çıkar Çatışması: Herhangi bir çıkar çatışmamız bulunmamaktadır. Finansal Destek: Çalışma için HÜBAK Kurumdan Destek Alındı. PROJE NUMARASI : 19019

\section{Kaynaklar}

1. Bozkurt $M$, Yüksel H, Em S, Oktayoğlu $P$, Yıldız $M$, Akdeniz D, Nas K. Serum prolidase enzyme activity and oxidative status in patients with Behçet's disease. Redox Report. 2014; 19:2, 59-64.

2. Lupi A, Tenni R, Rossi A, Cetta G, Forlino A. Human prolidase and prolidase deficiency: an overview on the characterization of the enzyme involved in proline recycling and on the 
effects of its mutations. Amino Acids. 2008; 35(4):739-52.

3. Altay MA, Ertürk C, Aksoy N. A prelimi- nary study pointing out the role of serum prolidase activity and oxidative-antioxidative status parameters during the treatment process of patients with idiopathic clubfoot. Scand JClin Lab Invest. 2011;71(7):5.

4. Vural M, Toy H, Camuzcuoglu H, Aksoy N. Comparison of prolidase enzyme activities of maternal serum and placental tissue in patients with early pregnancy failure. Arch Gynecol Obstet. 2010;283:953-958.

5. Surazynski A, Miltyk W, Palka J, Phang JM. Prolidasedependent regulation of collagen biosynthesis. Amino Acids. 2008;35:731-738.

6. Zhao L, Tian W, Pan H, Zhu X, Wang J, Cheng Z. Variations of the COL1A1 gene promoter and the relation to developmental dysplasia of the hip. Genet Test Mol Biomarkers. 2013;17(11):840-843.

7. Blatt SH. To swaddle, or not to swaddle? Paleoepidemiology of developmental dysplasia of the hip and the swaddling dilemma among the indigenous populations of North America. Am J Hum Biol. 2015;27(1):116-128.

8. Altay MA, Ertürk C, Levent A, Çetin BV, Aksoy N. Serum prolidase activity and oxidative-antioxidative status in patients with developmental dysplasia of the hip and its relationship with radiographic severity. Redox Rep. 2017; 22(5):227-234.

9. Aslankoç R, Demirci $D$, İnan Ü, Yıldız $M$, Öztürk $A$, Çetin $M$, Savran EŞ, Yılmaz B. The Role Of Antioxidant Enzymes in Oxidative Stress-Superoxide Dismutase (Sod), Catalase (Cat) And Glutathione Peroxidase (Gpx). Med J SDU. 2019; 26(3): 362-369.

10. Dündar Y, Aslan R. Oksidan-antioksidan Denge ve Korunmasında Vitaminlerin Rolü. Hayvancılık Araştırma Dergisi. 1999; 9(1-2): 32-39.

11. Koca N, Karadeniz F. Serbest Radikal Oluşum Mekanizmaları ve Vücuttaki Antioksidan Savunma Sistemleri. Gıda Mühendisliği Dergisi. 2003; 16: 32-37.

12. Şener $G$, Yeğen $B$ Ç. İskemi Reperfüzyon Hasarı. Klinik Gelişim. 2009; 22(3): 5-13.

13. Ekinci A, Kamasak K. Evaluation of serum prolidase enzyme activity and oxidative stress in patients with tinnitus. Braz J Otorhinolaryngol. 2020; 86(4): 405-410.

14. Kılıç E, Erek Toprak A, Kesgin Ayhan S, Baş A, Duruyen S. Şizofrenik hastaların atak ve remisyon dönemlerinde oksidatif stress. Gaziosmanpaşa Üniversitesi Tıp Fakültesi Dergisi. 2015;7(4):286-298.

15. Altunışık E. Migren hastalarında oksidatif metabolizmanın ve oksidatif dna hasarının etkisinin araştırılması. Uzmanlık Tezi, Gaziantep: Gaziantep Üniversitesi Tıp Fakültesi, 2015.

16. Phaniendra A, Jestadi D B, Periyasamy L. Free radicals: properties, sources, targets, and their implication in various diseases. Ind J Clin Biochem. 2015; 30(1): 11-26.

17. Altındağ $O$, Erel $O$, Aksoy $N$, Selek $S$, Çelik $H$, Karaoğlanoğlu $M$. Increased oxidative stress and its relation with collagen metabolism in knee osteoarthritis. Rheumatol Int. 2007;27:339-44.

18. Evrenkaya TR, Atasoyu EM, Kara M, Unver S, Gultepe M. The role of prolidase activity in the diagnOSIs of uremic bone disease. Ren Fail. 2006; 28:271-4.

19. Galicka A, Nazaruk J. Stimulation of collagen biosynthesis by fla- vonoid glycOSIdes in skin fibroblasts of osteogenesis imperfecta type I and the potential mechanism of their action. Int J Mol Med. 2007;20(6):889-95.
20. Altay MA, Ertürk C, Aksoy N, Taşkın A, Bilge A, Çelik H and Işıkan UE. Serum prolidase activity and oxidative-antioxidative status in Legg-Calve-Perthes disease. J Pediatr Orthop B. 2011;20(4):222-6.

21. Ertürk C, Altay MA, Selek $S$, Koçyiğit A. Paraoxonase-1 activity and oxidative status in patients with knee osteoarthritis and their relationship with radiological and clinical parameters. Scand J Clin Lab Invest. 2012;72(5):433-9.

22. Karakoç $\mathrm{M}$, Altındağ $\mathrm{O}$, Keleş $\mathrm{H}$, Soran $\mathrm{N}$, Selek S. Serum oxidative-antioxidative status in patients with ankylOSIng spondylitis. Rheumatol Int. 2007;27:1131-4. 